\title{
Metode Pengeringan Sari Pandan (Pandanus amaryllifolius) untuk Meningkatkan Kualitas Bubuk Sari Pandan
}

\author{
Nurwanto ${ }^{1}$, Antin Suswantinah ${ }^{2}$ \\ ${ }^{1}$ Nurwanto, Pilot Plant Proses Pangan SEAFAST Center, Lembaga Penelitian dan \\ Pengabdian Masyarakat, IPB University, Bogor 16680, nurwanto.ipb22@gmail.com \\ ${ }^{2}$ Antin Suswantinah, Departemen IImu Dan Teknologi Pangan, Fakultas Teknologi \\ Pertanian, IPB University, Bogor 16680, antinsw@yahoo.co.id
}

Submisi: 01 November 2021; Penerimaan: 30 Desember 2021

\begin{abstract}
ABSTRAK
Sari pandan merupakan hasil ekstraksi daun pandan. Sari pandan siap pakai yang beredar di Indonesia mayoritas berbentuk pasta, yang memiliki beberapa kelemahan, diantaranya mudah rusak, lengket, dan susah ditakar. Pembuatan sari pandan dalam bentuk bubuk diharapkan dapat meningkatkan mutu sari pandan. Metode yang digunakan dalam penelitian ini adalah pengeringan spray drying dan pengeringan vakum. Pengujian kadar air menunjukkan bahwa sari pandan yang dibuat dengan metode spray drying memiliki kadar air yang lebih rendah daripada metode pengeringan vakum. Pengamatan sifat fisik sari pandan dalam kondisi siap pakai menunjukkan bahwa metode spray drying menghasilkan warna dan aroma sari pandan yang lebih kuat daripada metode pengeringan vakum. Uji organoleptik menunjukkan bahwa panelis lebih menyukai warna dan aroma sari pandan yang dibuat dengan metode spray drying.
\end{abstract}

Kata kunci : bubuk; pengeringan vakum; sari pandan; spray drying

\section{Drying Method of Pandan Extract (Pandanus amaryllifolius) to Improve Powder Quality}

\begin{abstract}
Pandan extracts is made from pandan leaves. The majority of ready-to-use pandan extracts in Indonesia are in the form of pasta which has several disadvantages, including perishable, sticky, and hard to be measured. Pandan extract in powder form is expected to improve the quality of the pandan extract. The method used in this study are spray drying and vacuum drying. Water content analysis shows that pandan extract made by spray drying method has a lower moisture content than the vacuum drying method. Observation of the physical properties of pandan extract in ready-to-use form showed that the spray drying method produced stronger color and aroma than the vacuum drying method. Organoleptic tests showed that panelists preferred the color and aroma of pandan extract made using the spray drying method.
\end{abstract}

Keywords : pandan extract; powder; spray drying; vacuum drying

\section{PENDAHULUAN}

\section{Pengantar}

Dewasa ini, moderenisasi menimbulkan tuntutan baru kepada masyarakat untuk melakukan aktivitas- aktivitasnya dengan efektif dan efisien, termasuk dalam kegiatan masakmemasak. Hal ini menyebabkan penggunaan bumbu siap pakai yang praktis digunakan menjadi salah satu kebutuhan masyarakat Indonesia. Saat 
ini, banyak sekali penggunaan bumbu siap pakai dalam masakan Indonesia [1].

Pandan (Pandanus amaryllifolius) adalah salah satu tanaman asli Indonesia yang banyak digunakan sebagai pewangi makanan, dan pewarna makanan. Ekstrak pandan segar memiliki sifat mudah rusak sehingga perlu diaplikasikan teknologi pangan untuk menambah umur simpannya [2].

\section{Tujuan}

Tujuan dari penelitian ini adalah untuk mencari metode pengeringan sari pandan yang berkualitas, khususnya dari segi aroma dan warna.

\section{Latar Belakang}

Produk pandan siap pakai yang banyak ditemukan di Indonesia adalah ekstrak dalam bentuk pasta. Kelemahan ekstrak dalam bentuk pasta diantaranya adalah mudah rusak karena kandungan airnya yang relatif tinggi, serta sulit untuk ditakar saat akan digunakan karena sifatnya yang lengket pada wadah [3].
Pemanfaatan pandan dalam bentuk lain seperti bubuk belum banyak ditemukan di Indonesia. Hambali [3] menyebutkan bahwa pengeringan dalam bentuk bubuk memiliki beberapa keunggulan, diantaranya tidak lengket, mudah ditakar, dan lebih awet karena kadar airnya rendah.

Penelitian ini bertujuan untuk mengetahui metode pengeringan yang dapat menghasilkan bubuk sari pandan yang berkualitas. Metode pengeringan yang diujikan adalah metode pengering vakum dan spray drying.

\section{METODE}

\section{Bahan}

Bahan yang digunakan dalam penelitian ini adalah daun pandan, alkohol 70\%, akuades, maltodekstrin, dan kemasan plastik. Daun pandan diperoleh dari Laladon Indah, Dramaga, Bogor, Indonesia. Maltodekstrin dan alkohol $70 \%$ teknis yang dibeli dari toko Setia Guna, Bogor, Indonesia.

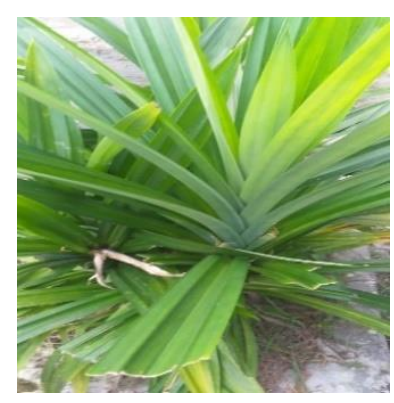

Gambar 1. Daun Pandan

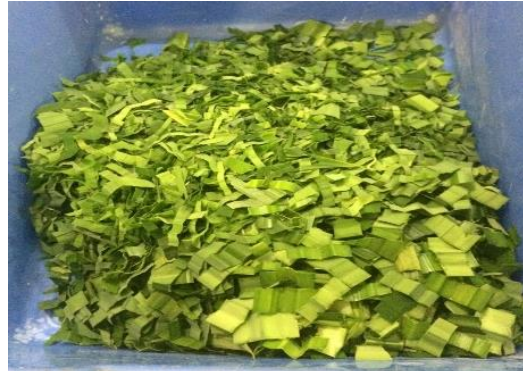

Gambar 2. Daun pandan yang telah dipotong
Alat

Alat yang digunakan dalam penelitian ini adalah spray dryer merek Buchi (mini spray dryer 190, tekanan semprot 5-8 bar, suhu maksimal $220^{\circ} \mathrm{C}$, daya listrik $2900 \mathrm{~W}$ ), vacuum evaporator merek Ogawa (tipe Pan, 600 rpm, pompa vakum 300 L/jam, kapasitas $40 \mathrm{~L}$ ), homogenizer merek Armfield, blender merek Philips, plastic sealer merek
Powerpack, cawan, gegep, timbangan, kain saring, pisau, gunting, baskom plastik, talenan, nampan, dan gelas ukur.

\section{Pembuatan Bubuk Sari Pandan dengan Metode PengeringanVakum}

Daun pandan seberat 200 gram dipotong $0,5-1,0 \mathrm{~cm}$. Kemudian membuat larutan maltodekstrin sebanyak $30 \%$ dari bobot daun pandan yang dilarutkan ke dalam $250 \mathrm{~mL}$ 
akuades kemudian dihomogenisasi selama 2 menit dengan kecepatan 13000 rpm. Daun pandan yang sudah dipotong dimasukkan ke dalam blender dan ditambahkan alkohol $70 \%$ sebanyak 500 $\mathrm{mL}$. Sampel kemudian diblender selama 2 menit lalu ditambahkan kembali $500 \mathrm{~mL}$ alkohol $70 \%$ dan diblender selama 2 menit. Sampel kemudian dituangkan ke dalam baskom plastik yang sudah ditutupi kain saring lalu diperas sampai kering. Alkohol $70 \%$ sebanyak $750 \mathrm{~mL}$ ditambahkan secara bertahap pada ampas pandan untuk membilas kemudian diperas kembali. Sari pandan hasil pemerasan kemudian dipindahkan ke wadah lain dan dicampurkan dengan larutan maltodekstrin untuk dihomogenisasi dengan kecepatan 13000 rpm selama 2 menit. Sari pandan yang telah dihomogenisasi kemudian dikeringkan menggunakan vacuum evaporator dengan suhu $70^{\circ} \mathrm{C}$,tekanan $70 \mathrm{cmHg}$ selama 1 jam. Sari pandan yang telah kering kemudian diblender sampai halus, ditimbang, dan dikemas dalam kemasan yang kedap udara. Diagram alir pembuatan sari pandan metode pengeringan vakum disajikan pada Gambar 8.

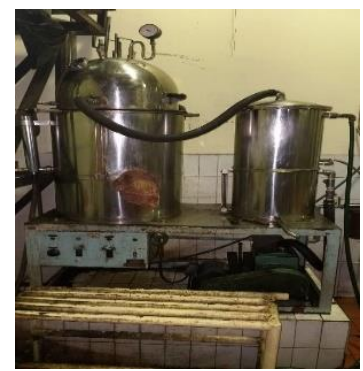

Gambar 3. Alat vacuum evaporator

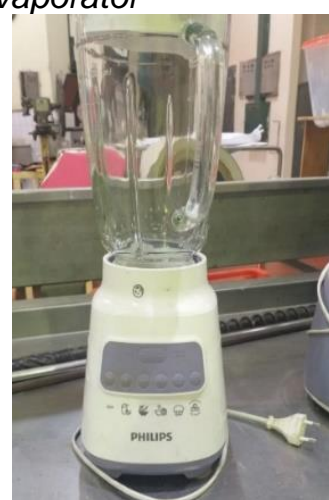

Gambar 6. Alat blender

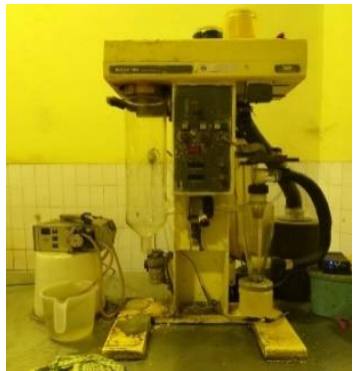

Gambar 4. Alat spray dryer

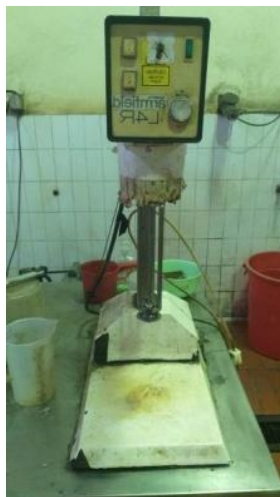

Gambar 5. Alat homogenizer

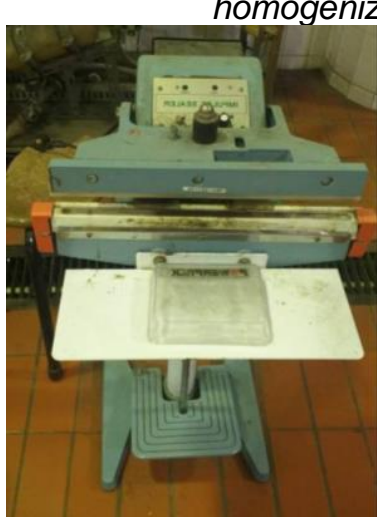

Gambar 7. Alat sealer

\section{Pembuatan Bubuk Sari Pandan dengan Metode Spray Drying [6]}

Daun pandan seberat 200 gram dipotong $0,5-1,0 \mathrm{~cm}$. Dalam waktu bersamaan, dilakukan pembuatan larutan maltodekstrin. Maltodekstrin sebanyak $30 \%$ bobot daun pandan dilarutkan ke dalam $250 \mathrm{~mL}$ akuades kemudian dihomogenisasi selama 2 menit dengan kecepatan $13000 \mathrm{rpm}$. Daun pandan yang sudah dipotong dimasukkan ke dalam blender dan ditambahkan alkohol $70 \%$ sebanyak 500 
$\mathrm{mL}$. Sampel kemudian diblender selama 2 menit lalu ditambahkan kembali $500 \mathrm{~mL}$ alkohol $70 \%$ dan diblender selama 2 menit. Sampel kemudian dituangkan ke dalam baskom plastik yang sudah ditutupi kain saring lalu diperas sampai kering. Alkohol 70\% sebanyak $750 \mathrm{~mL}$ ditambahkan secara bertahap pada ampas pandan untuk membilas kemudian diperas kembali. Sari pandan hasil pemerasan kemudian dipindahkan ke wadah lain dan dicampurkan dengan larutan maltodekstrin untuk dihomogenisasi dengan kecepatan 13000 rpm selama 2 menit. Sari pandan yang telah dihomogenisasi kemudian dikeringkan menggunakan spray dryer dengan suhu inlet $170^{\circ} \mathrm{C}$ dan suhu outlet $70^{\circ} \mathrm{C}$. Sari pandan yang telah kering kemudian diblender sampai halus, ditimbang, dan dikemas dalam kemasan yang kedap udara. Diagram alir pembuatan sari pandan metode spray drying disajikan pada Gambar 8.

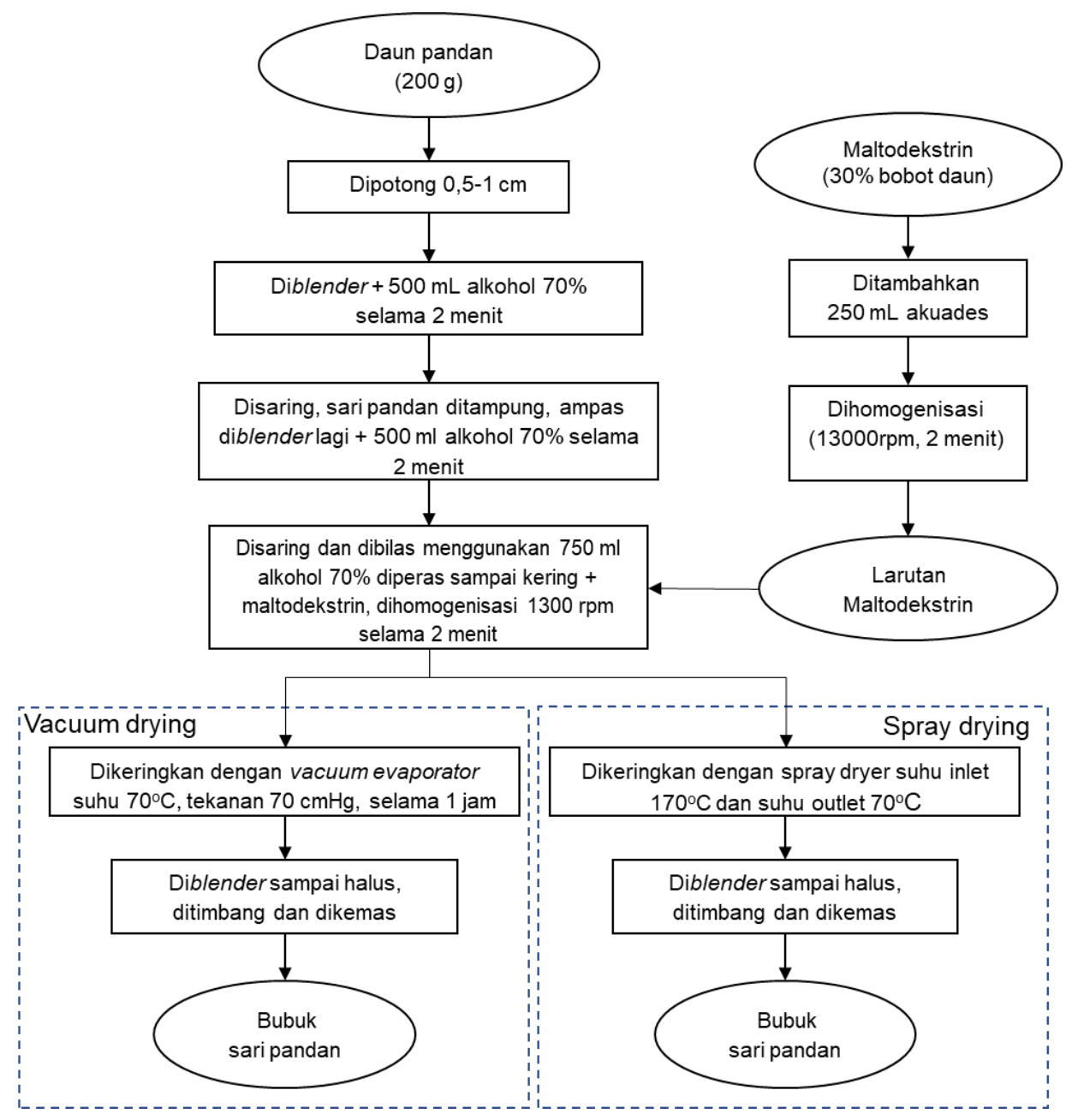

Gambar 8. Diagram alir pembuatan bubuk sari pandan

\section{Pengamatan Sifat Fisik Bubuk Sari Pandan [11]}

Pengamatan sifat fisik sari pandan diawali dengan mengamati warna dan aroma sampel dalam bentuk bubuk, dilanjutkan sampel siap pakai yang dibuat dengan mengencerkan bubuk sari pandan dengan menggunakan akuades. Pengamatan dilakukan sebanyak dua kali ulangan Volume akuades yang digunakan adalah sebanyak 10x bobot sampel bubuk sari pandan. Setelah 
ditambahkan akuades, sampel didiamkan selama 5 menit lalu diamati aroma dan warnanya.

\section{Analisis Kadar Air Metode Oven [4]}

Cawan kosong dikeringkan dalam oven yang bersuhu 105ㅇ hingga mencapai bobot yang konstan kemudian didinginkan dalam desikator. Cawan diambil menggunakan penjepit dan ditimbang. Sampel sebanyak 1-2 gram dimasukkan ke dalam cawan dan dikeringkan di dalam oven pada suhu $105^{\circ} \mathrm{C}$ selama tiga jam hingga mencapai bobot konstan. Setelah selesai, sampel diambil dengan penjepit lalu didinginkan di dalam desikator dan ditimbang. Perhitungan kadar air menggunakan Persamaan 1

$$
\begin{aligned}
& \mathrm{KA}(\% \mathrm{WB})=\frac{\mathrm{W}-(\mathrm{W} 1-\mathrm{W} 2)}{W} \times 100 \% \\
& \text { Keterangan: } \\
& \mathrm{W}=\text { Berat contoh sebelum } \\
& \text { dikeringkan }(\mathrm{g}) \\
& \mathrm{W} 1=\text { Berat contoh setelah } \\
& \text { dikeringkan + cawan kosong }(\mathrm{g}) \\
& \mathrm{W} 2 \text { = Berat cawan kosong }(\mathrm{g})
\end{aligned}
$$

\section{Analisis Organoleptik [5]}

Uji organoleptik dalam penelitian ini mengunakan dua parameter yaitu aroma dan warna. Sampel yang digunakan adalah sari pandan yang telah siap digunakan, yaitu dengan diencerkan 10x menggunakan akuades. Sebanyak 30 orang panelis [5] disajikan sampel dalam cawan, kemudian mengisikan penilaiannya pada formulir uji organoleptik dengan 7 skala rating kesukaan yaitu : 1 (sangat tidak suka), 2 (tidak suka), 3 (agak tidak suka), 4 (netral), 5 (agak suka), 6 (suka), 7 (sangat suka).

\section{Pengolahan Data [5] \\ Pengolahan data dilakukan dengan menggunakan program Microsoft Excel 2007 dan IBM SPSS Statistics 20. Microsoft Excel digunakan}

untuk mengolah rata-rata kadar air dan SPSS digunakan untuk mengolah hasil uji organoleptik

\section{HASIL DAN PEMBAHASAN}

Penelitian ini terdiri atas dua tahap, yaitu pembuatan bubuk sari pandan dan pengujian mutu yang meliputi pengamatan fisik yang mencakup warna dan aroma, pengujian kadar air dan organoleptik. Sampel bubuk sari pandan dibuat sebanyak dua kali ulangan. Pada pengamatan sifat fisik bubuk sari pandan, sari pandan yang dibuat dengan metode spray drying memiliki warna yang lebih pudar daripada metode pengeringan vakum. Hal ini disebabkan oleh terjadinya enkapsulasi zat warna pandan oleh maltodekstrin dalam pengeringan spray drying [6]. Dalam proses pengeringan vakum, hal ini tidak terjadi, sehingga warna sari pandan yang dihasilkan lebih kuat intensitasnya. Aroma sari pandan yang dihasilkan dengan metode spray drying lebih lemah daripada metode pengeringan vakum. Hal ini disebabkan oleh enkapsulasi komponen aroma pandan pada metode spray drying sehingga aromanya berkurang intensitasnya. Produk bubuk sari pandan hasil pengeringan dengan metode spray drying (kiri) dan metode pengeringan vakum (kanan) disajikan pada Gambar 9.

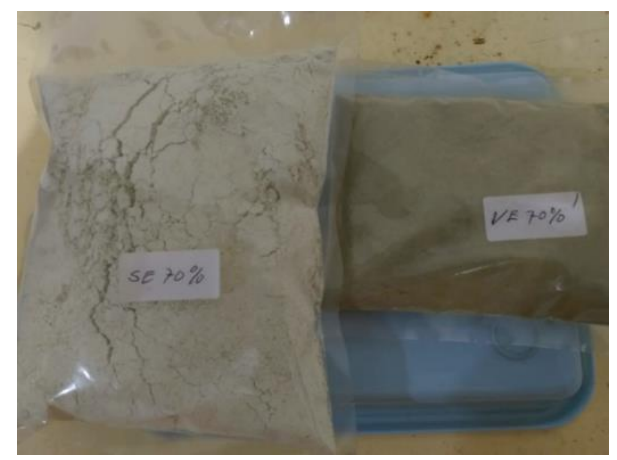

Gambar 9. Sari pandan metode spray drying (kiri) dan pengeringan vakum (kanan) 


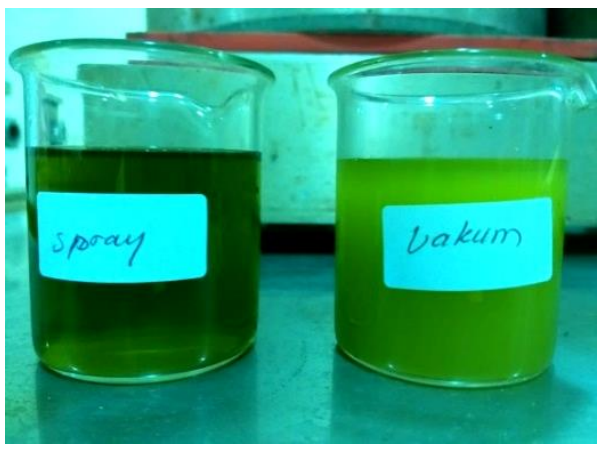

Gambar 10 . Sari pandan dengan pengenceran $10 x$

Pengamatan fisik dilanjutkan dengan mengamati sifat fisik sampel sari pandan pada keadaan siap digunakan. Sari pandan dilarutkan dengan akuades pada pengenceran 10x, kemudian diamati warna dan aromanya. Gambar 10 menunjukkan keadaan sampel setelah diencerkan. Pengamatan warna secara visual menunjukkan bahwa sari pandan yang dibuat dengan metode spray drying lebih pekat warnanya dibandingkan dengan metode pengeringan vakum. Hal ini disebabkan oleh adanya proses enkapsulasi oleh maltodekstrin yang melindungi komponen warna pada pandan sehingga tidak rusak oleh panas. Saat dilarutkan dengan akuades, komponen warna tersebut terlepas dan memberikan warna yang kuat pada larutan [7]. Pada pengeringan dengan metode pengeringan vakum, tidak terjadi proses enkapsulasi, sehingga panas yang digunakan dalam proses pengeringan akan merusak komponen warna sehingga warnanya lebih pudar daripada metode spray drying.

Pada pengamatan aroma, sampel sari pandan metode spray drying yang telah diencerkan memiliki aroma yang lebih kuat daripada sampel metode pengeringan vakum. Mufarida [6] menyatakan bahwa dalam proses pengeringan menggunakan alat spray dryer, kontak panas yang terjadi dengan bahan berlangsung dengan sangat singkat, yaitu hanya dalam beberapa detik, sehingga komponen aroma yang bersifat volatil tidak rusak. Dalam pengeringan metode pengeringan vakum diperlukan waktu sekitar 15 menit untuk mencapai tekanan akhir $70 \mathrm{cmHg}$, sehingga lebih banyak komponen aroma yang rusak oleh panas dibandingkan dengan metode spray drying. Terjadinya enkapsulasi komponen aroma oleh maltodekstrin pada metode spray drying juga berperan mempertahankan aroma sari pandan. Berdasarkan hasil pengamatan sifat fisik, karena dalam penggunaannya sari pandan akan diencerkan terlebih dahulu, maka dapat ditarik kesimpulan bahwa sampel metode spray drying lebih baik daripada metode pengeringan vakum, karena memiliki warna dan aroma yang lebih kuat.

Penelitian ini dilanjutkan dengan pengujian kadar air pada produk bubuk sari pandan yang dihasilkan. Menurut Hutasoit [8], umur simpan merupakan salah satu faktor terpenting dalam pengembangan produk pangan. Herawati [9] menyatakan bahwa kadar air merupakan faktor penting yang mempengaruhi umur simpan pangan. Kedua pernyataan tersebut menegaskan pentingnya peranan kadar air dalam menentukan keawetan produk pangan. Pengujian kadar air dalam penelitian ini dilakukan duplo dengan menggunakan metode oven yang mengacu pada AOAC. Hasil pengujian kadar air disajikan pada Tabel 1

Berdasarkan hasil pengujian, ratarata kadar air sampel yang dikeringkan dengan metode pengeringan vakum mengandung kadar air rata-rata sebesar $7.44 \%$, lebih tinggi daripada metode spray drying sebesar $4,65 \%$. Troller dan Christian [10] menyatakan bahwa bila suatu bahan pangan memiliki kadar air yang semakin tinggi akan berdampak pada stabilitasnya dan akan 
meningkatkan potensi kerusakan pangan oleh mikroba. Sehingga, bubuk sari pandan yang dikeringkan dengan menggunakan metode spray drying akan memiliki umur simpan yang lebih panjang karena kadar airnya lebih rendah.

Tabel 1. Data pengujian kadar air bubuk sari pandan

\begin{tabular}{ccccc}
\hline Sampel & Ulangan & $\begin{array}{c}\text { KA } \\
(\%)\end{array}$ & $\begin{array}{c}\text { Rerata } \\
\text { KA } \\
(\%)\end{array}$ & $\begin{array}{c}\text { Rerata } \\
\text { KA } \\
\text { Metode } \\
(\%)\end{array}$ \\
\hline VU1 & 1 & 7,52 & 7,48 & \\
& 2 & 7,43 & & 7,44 \\
VU2 & 1 & 7,47 & 7,41 & \\
& 2 & 7,35 & & \\
SU1 & 1 & 4,73 & 4,71 & \\
& 2 & 4,68 & & 4,65 \\
SU2 & 1 & 4,63 & 4,60 & \\
\hline
\end{tabular}

Uji organoleptik dilakukan untuk mengetahui penerimaan konsumen. Parameter yang diujikan adalah aroma dan warna. Respon panelis hasil uji organoleptik diolah dengan fitur descriptive statistics pada program SPSS 20. Hasil pengujian disajikan pada Tabel 2.

Tabel 2. Rata-rata skor uji organoleptik kesukaan aroma dan warna

\begin{tabular}{llll}
\hline Parameter & Ulangan & $\mathrm{N}$ & Rerata \\
\hline Aroma & 1 & 30 & 1,43 \\
Total & 2 & 30 & 6,57 \\
\hline \multirow{2}{*}{ Warna } & 1 & 60 & 4,00 \\
Total & 2 & 30 & 1,47 \\
\hline
\end{tabular}

Dalam Tabel 2, nilai rata-rata skor aroma sampel 1 (metode pengeringan vakum) lebih rendah daripada sampel 2 (metode spray drying). Skor rata-rata aroma metode pengeringan vakum adalah 1,43 . Nilai ini masuk ke dalam interval penilaian 1 dan 2, yaitu antara sangat tidak suka dan tidak suka. Skor rata-rata aroma sampel metode spray drying adalah 6,57. Nilai ini masuk ke dalam interval penilaian 6 dan 7, yaitu antara suka dan sangat suka. Nilai ratarata skor warna sampel 1 (metode pengeringan vakum) juga lebih rendah daripada sampel 2 (metode spray drying). Skor rata-rata warna metode pengeringan vakum adalah 1,47 . Nilai ini masuk ke dalam interval penilaian 1 dan 2 , yaitu antara sangat tidak suka dan tidak suka. Skor rata-rata warna sampel metode spray drying adalah 6,70. Nilai ini masuk ke dalam interval penilaian 6 dan 7 , yaitu antara suka dan sangat suka. Berdasarkan hasil pengolahan data dengan SPSS, dapat disimpulkan bahwa panelis cenderung lebih menyukai aroma dan warna sampel yang dibuat dengan metode spray drying daripada pengeringan vakum.

\section{PENUTUP}

\section{Kesimpulan}

Pengamatan sifat fisik terhadap sampel bubuk sari pandan menunjukkan bahwa sampel sari pandan metode spray drying memiliki warna yang lebih cerah dan aroma yang lebih rendah intensitasnya daripada sampel metode pengeringan vakum. Setelah sampel diuji pada kondisi siap digunakan, yaitu dengan dilarutkan menggunakan akuades, warna dan aroma sampel metode spray drying lebih kuat daripada metode pengeringan vakum. Hasil uji organoleptik menunjukkan bahwa panelis lebih menyukai warna dan aroma sampel sari pandan yang dibuat dengan metode spray drying. Berdasarkan uji kadar air, pengamatan sifat fisik warna dan aroma sari pandan dalam bentuk larutan yang siap digunakan, serta uji organoleptik, dapat disimpulkan bahwa sari pandan yang dibuat dengan metode spray drying lebih baik daripada metode pengeringan vakum.

\section{Saran}

Saran untuk penelitian selanjutnya, agar dilakukan penelitian lanjutan untuk mengetahui parameter optimal yang dapat digunakan untuk 
pengeringan sari pandan dengan metode vakum dan spray drying.

\section{UCAPAN TERIMA KASIH}

Ucapan terima kasih disampaikan kepada Kepala SEAFAST Center LPPM yang telah memberikan fasilitas untuk penelitian.

\section{DAFTAR PUSTAKA}

[1] Erwin LT. 2011. Seri jadi Koki Sekejap : Masak Sajian dari Bumbu Dasar dalam Waktu 30: PT Gramedia Pustaka Utama. Menit. Jakarta (ID).

[2] Palupi IA, Ndhiha BBA, Trihandaru S. 2014. Identifikasi Pigmen Daun Pandan Wangi (Pandanus amaryllifolius) dengan Spektrofotometer Sederhana. [Karya Ilmiah].: Universitas Kristen Satya Wacana. Salatiga (ID)

[3] Hambali E, Fatmawati, dan Permanik R. 2007. Membuat Aneka Bumbu Instan Kering.: Penebar Swadaya. Jakarta (ID).

[4] [AOAC] Association of Official. Analytical Chemistry. 2005. Official Methods of Analysis. AOAC. Washington DC (US).

[5] Rohimah I, Sudaryati E, Nasution E. 2013. Analisis Energi dan Protein serta Uji Daya Terima Biskuit
Tepung Labu Kuning dan Ikan Lele. Jurnal Gizi, Kesehatan Reproduksi dan Epidemiologi Vol 2, No 6.

[6] Mufarida NA. 2016. Perpindahan Panas dan Massa pada Spray Dryer. CV Pustaka Abadi. Jember (ID).

[7] Audrey. 2018. Pengembangan Serbuk Pewarna Alami Angkak (Monascus Sp.) dengan Berbagai Metode Pengeringan dan Konsentrasi Soy Protein Isolate sebagai Enkapsulan. [Skripsi]. Universitas Katolik Soegijapranata. Semarang (ID).

[8]Hutasoit, N. 2009. Penentuan Umur Simpan Fish Snack (Produksi Ekstrusi) Menggunakan Metode Akselerasi dengan Pendekatan Kadar Air Kritis dan Metode Konvensional. [Skripsi]. Institut Pertanian Bogor. Bogor (ID).

[9] Herawati H. 2008. Penentuan Umur Simpan pada Produk Pangan. Jurnal Litbang Pertanian, 27(4) : 124-130.

[10] Troller J.A, J.H.B. Christian. 1978. Water Activity and Food. Academic Press. New York (US).

[11] Bianca K. 1993. Pengaruh Penambahan $\mathrm{ZnCl} 2$ dalam Pembuatan Ekstrak Warna dari Campuran Daun Suji dan Daun Pandan [Skripsi]. IPB University. Bogor (ID). 